\title{
Ben Thirkell-White
}
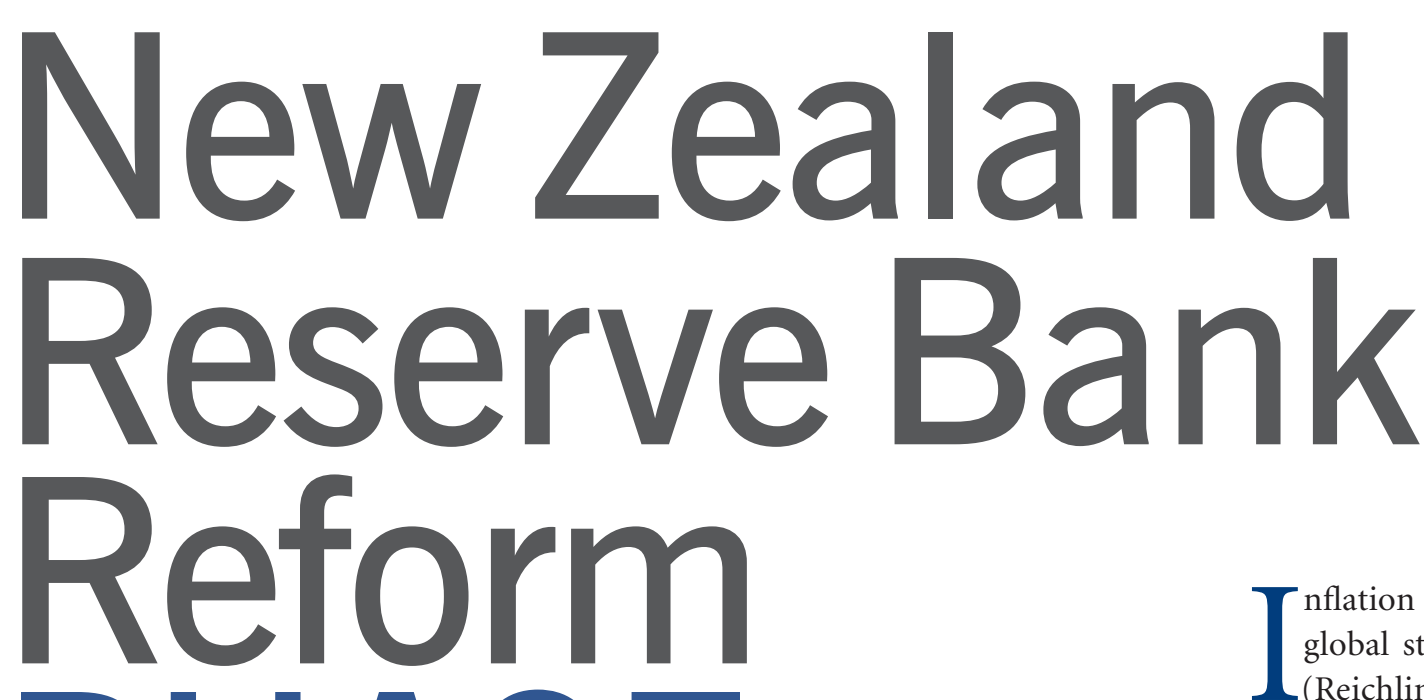

Tnflation targeting, now the de facto global standard for monetary policy
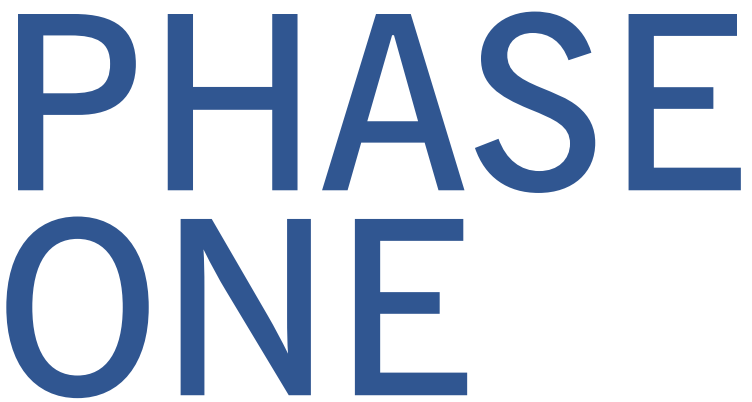

(Reichlin and Baldwin, 2013), was invented in New Zealand. It was introduced with the Reserve Bank Act in 1989, was widely admired and spread globally during the 1990s. The Reserve Bank's institutions have been praised by experts as a particularly pure embodiment of inflation-targeting theory (Walsh, 1995) and inflation was decisively tamed in the early 1990s.

However, late last year, significant changes were made to the Reserve Bank's mandate and institutional structure under

\section{Abstract}

The inflation-targeting approach to central banking was invented in New Zealand, before becoming the global standard during the 1990s. Despite this popularity, significant reforms were introduced to the Reserve Bank Act in late 2018 as part of a two-stage review, notably an expanded mandate and a committee decision-making structure. This article reviews the changes in the light of global and domestic challenges to central banking emerging since the global financial crisis.

Keywords Reserve Bank of New Zealand, central banking, quantitative

$$
\text { easing, political economy }
$$

Ben Thirkell-White is Associate Professor of International Relations at Victoria University of Wellington and an expert on democracy and financial governance. the New Zealand Reserve Bank Amendment Act - the first phase of a major two-phase review. Under the new arrangements, the bank is no longer concerned only with price stability but must also 'contribute to maximum sustainable levels of employment'. Decision making on monetary policy has been transferred from the bank's governor to a Monetary Policy Committee.

After a brief New Zealand-oriented review of the logic of inflation targeting, this article explores the domestic and international challenges for central banking that have emerged since the global financial crisis. Economists generally remain convinced by the inflation-targeting framework in 'normal times'. However, 
central banks' mandates have been expanding in ways that take them into more sensitive and less economically settled areas of policymaking. Meanwhile, there are signs that publics are increasingly concerned about the distributional impact of monetary policy.

The New Zealand reforms enhance the Reserve Bank's public openness and institutionalise some existing good practice. They also slightly increase its policy flexibility, but some important issues require further work, particularly if the bank finds itself needing to prevent deflation while interest rates are approaching zero.

\section{The political economy of inflation targeting}

The 1980s were a period of dramatic change in economic management worldwide. The Bretton Woods system of fixed exchange rates had broken down in the early 1970s. Two oil shocks followed, along with a period of high inflation and painful adjustment. Across the developed world, macroeconomic management shifted from attempting to deliver full employment in a highly regulated environment, to providing price stability under floating exchange rates, free capital flows and domestic financial liberalisation (Helleiner, 1994; James, 1996). In New Zealand this period was associated with turbulent disputes over macroeconomic management, particularly under Robert Muldoon. ${ }^{1}$

New Zealand's monetary policy had previously operated through controls on bank lending. With financial and exchange rate liberalisation the Reserve Bank shifted to a new role of influencing money and credit growth through 'open market operations'. This was new territory internationally and there was little consensus on how banks should calibrate their policy. Communicating a new-found commitment to fighting inflation in New Zealand was proving difficult. Meanwhile, politically, Roger Douglas wanted to 'Muldoon proof' monetary policy and both Treasury and Reserve Bank advisors were trying to work out how to fit the Reserve Bank into the government's redesign of public sector management.

Inflation targeting addressed all these issues. It fitted with the new public sector vision by providing a single measure for bank performance against which the governor could be held contractually responsible. How to deliver the target could then be left to the technical judgement of bank staff, free from political interference. Meanwhile, it gave the bank a clear policy goal towards which to orient its technical practice. The bank had been broadly sympathetic to overseas experiments with monetarism but had noticed difficulties in implementation. There were doubts over whether the bank had the power to deliver an inflation target, but bank staff generally liked its clarity, which corresponded with political expectations and provided a clear signal to markets that the bank wanted inflation well below the 5-6\% range. have to do less in terms of monetary tightening to achieve the same effect (stable prices), since markets will adjust their expectations and pricing following the bank's lead. The mere announcement of an inflation target will approximate a selffulfilling prophecy.

Against that broad consensus, there is scope for variation in institutional design. The original Reserve Bank Act tended to emphasise the bank's inflation-fighting credibility over its duty to justify itself to the public (Eichbaum, 2009). The single decision-maker model was particularly out of step with what became an international norm of committee decision making, which creates greater transparency over

\section{The single decision-maker model was particularly out of step with what became an international norm of committee decision making, which creates greater transparency over how decisions are reached.}

Finally, greater independence and transparency would remove politicians' temptation to manipulate monetary policy for short-term electoral gain.

Since 1990, inflation targeting has become the de facto global standard for central banking and its rationale has been explored and elaborated in a large academic literature (Alesina and Stella, 2010). The modern justification begins with a timeinconsistency problem. Monetary stimulus can create a short-term economic boost but, in the process, risks damaging medium-term growth through inflation. Democratic politicians have incentives to value short-term expediency over longerterm welfare. It therefore makes sense to assign policymaking to a politically insulated independent agency. Not only does this produce better short-term policy. It also alters market expectations of inflation. That is important because wages and prices throughout the economy are set based on expected future price levels. If a central bank can acquire credibility, it will how decisions are reached. In the early years there were also signs of a particularly strict interpretation of the inflation target. However, informal practice evolved to soften both of these elements over time.

\section{Adaptation, trade-offs and criticism in New} Zealand: towards 'flexible inflation targeting' While inflation targeting became the consensus approach to monetary policy, it remained subject to minority criticism, particularly from the political left, on the grounds that it overemphasises price stability, seeing other effects of monetary policy as unavoidable residuals. So, if a country chooses to target price stability and allow capital to flow freely across its borders, it must take the consequences in terms of exchange rate movements. A 'strict' inflation target, in which that is the only criterion for monetary policy, would also imply that levels of employment and output were also a 'residual'. Although monetary policy cannot affect levels of output over the long term, there is a short- 
term trade-off in which tighter monetary policy designed to stabilise prices also reduces levels of output and employment.

The inflation-output trade-off has distributional consequences, though these are difficult to specify with any generality and don't map tidily onto a traditional leftright political spectrum (Kirshner, 2001). Tight monetary policy tends to favour savers and lenders over borrowers (by increasing interest rates and limiting the inflationary erosion of loan value). It may also help those on low incomes who find it difficult to obtain wage increases as price levels rise and who are vulnerable to small was highly critical of the Reserve Bank on these grounds in opposition during the mid-1990s, and later, as finance minister, commissioned Lars Svensson to conduct an external review of monetary policy (Svensson, 2001). Another review was commissioned by the incumbent centreleft Labour government in 2007, and the Labour and Green parties in opposition were both highly critical of monetary policy throughout the post-global financial crisis period. Criticism has tended to argue that, under uncertainty, the Reserve Bank has been happier to risk unemployment than it has to risk price instability. ${ }^{3}$

\section{In terms of governance structures, the Svensson review suggested moving to committee-based decision making, but the bank was reluctant and the Labour government did not press the point.}

changes. Traditionally, advocates of tight money have emphasised the latter effect as dominant, arguing that inflation is 'the cruelest tax'. However, recent econometric work suggests, somewhat tentatively, that unexpected interest rate increases in a context of low to moderate inflation can have regressive distributional consequences overall. ${ }^{2}$ Finally, there is a clear tendency for financial sector actors to prefer tight monetary policy (Adolph, 2013; Posen, 1995), while the real sector is more divided, depending on how monetary policy interacts with other variables, particularly the exchange rate.

In New Zealand, the Reserve Bank has tended to face particular criticism when relatively high interest rates have encouraged capital inflows, boosting house prices and putting upward pressure on the exchange rate. High interest rates can make New Zealand an attractive short-term destination for overseas investors. Given relatively thin capital markets, inflows find their way into the domestic banking system and a combination of banks' and borrowers' preferences means funds are lent on to the domestic property sector. Michael Cullen
In practice, the bank has not generally behaved like an 'inflation nutter'. At least by 2000, Svensson argued, the bank had followed best practice in moving to a 'flexible' inflation-targeting regime in which it sought to hit its inflation target on average over the medium term, but showed some flexibility where rapid monetary tightening would be too detrimental for output (Svensson, 2001). However, the bank has still struggled to deal with the exchange rate problem. Under previous governor Graeme Wheeler, the bank defended the view that its primary goal was price stability and that there was ultimately little monetary policy could do about exchange rate movements. The Reserve Bank did not have sufficient resources to intervene effectively in foreign exchange markets and it did not make sense to trade off inflation risks against a lower exchange rate. A medium-term solution to the problem would need to come through structural change, particularly increasing New Zealand's saving rates (Wheeler, 2013). ${ }^{4}$

In terms of governance structures, the Svensson review suggested moving to committee-based decision making, but the bank was reluctant and the Labour government did not press the point. However, the issue didn't go away, with Treasury suggesting it in internal advice in 2011 and Russel Norman, co-leader of the Greens, introducing a private member's bill on Reserve Bank reform in 2013 that included moving to a committee model.

Despite a global elite consensus on inflation targeting, the Reserve Bank has faced ongoing low-level criticism since the 1989 legislation was introduced. Over time bank practice has evolved towards greater openness and a more flexible interpretation of its inflation target. Whatever the merits of the ongoing arguments over whether inflation control is politically neutral, this criticism has been stronger from the left. Criticism has been particularly strong where interest rates designed to control prices have also triggered exchange rate rises that harm exporters. However, even in the post-crisis period, it is probably fair to say that criticism remains an elite preoccupation, with limited popular political salience.

\section{Political challenges and 'the new central banking'}

Elsewhere, though, the world's most prominent central banks have come under greater political pressure (Blinder et al., 2017; Buiter, 2014; Riles, 2018). This pressure is driven by a combination of the technical challenges of the postcrisis environment and a shifting political mood, in which greater salience is given to inequality and scepticism of technocratic elites has grown.

The crisis made it particularly clear that price stability was not enough to ensure financial stability. Large-scale banking crises highlighted financial market failures. Central banks have bolstered their financial stability policies and many have adopted 'macroprudential tools'. Macroprudential regulation can 'lean against the wind' of boom and bust patterns in financial markets driven by herd effects and desensitisation to risk over time. Although interest rates could perform this role, they are a blunt instrument, affecting real sector activity as well as financial vulnerabilities. Macroprudential tools target credit growth more directly by rules on bank lending either in general (varying capital adequacy requirements) or to particular sectors (loan to value or loan to income restrictions in residential lending). 
Macroprudential policy is less well understood economically than traditional monetary policy and has more obvious distributional impacts. Interactions between interest rates and macroprudential policy also begin to muddy the clean 'single instrument, single goal' picture that underpinned inflation targeting.

Additionally, major central banks found themselves at the 'zero lower bound' of interest rate policy, while risks of deflation persisted. They have responded with unconventional monetary policy, including quantitative easing (QE). QE involves banks 'creating money' to buy long-term 'safe' assets, making these more expensive and so encouraging banks to increase lending and other financial sector actors to shift resources into riskier assets that are more likely to stimulate output growth.

QE demonstrated that central banks had greater powers than many had realised. There were doubts about how well it would work. Meanwhile, it had clear distributional consequences, raising asset prices, which would tend to benefit the already wealthy more than lower income groups. Where the asset in question was housing this could be particularly sensitive given housing's dual status as a financial asset and a necessary place for human shelter. ${ }^{5}$ The Bank of England has tried to argue that QE was 'neutral' in that it didn't significantly alter the wealth distribution (Bunn, Pugh and Yeates, 2018). However, fiscal policy would have been an alternative instrument and could (at least theoretically) have been designed in much more progressive ways (Wren-Lewis, 2011).

More generally, quantitative easing raises difficult political economy questions about the relationship between fiscal and monetary policy. At least some central bankers have argued that responses to deep recessions in the United States and Europe evolved into a game of 'chicken' between central bank and governments over the balance between fiscal and monetary stimulus. Contrary to the assumptions of the political economy of the inflationary 1970s, politicians have been reluctant to bear the 'political costs' of fiscal stimulus and have left it to central bankers (El-Erian, 2017). In other words, QE may have had regressive consequences, but it is unfair to lay this problem solely at the door of central banks, since they would not have had to embark on QE if politicians had been willing to deliver greater fiscal stimulus. QE raises important issues around the political consequences of isolating monetary policy from democratically governed fiscal policy, at least in times of crisis. ${ }^{6}$

Overall, central banks' power has expanded, moving banks into areas where the underlying economics is less certain and distributional consequences more direct. Unfortunately, this has taken place at a time when public confidence in financial elites is at an all-time low and concerns about inequality have become more politically salient. In technical terms, there are few independence. Central banks' postcrisis activities have complicated the simple picture of single-goal, single-tool monetary policy that underpinned the original vision for inflation targeting. There is pressure across economic policy to take distributional issues into account and arguments about technocratic expertise have come under renewed pressure. New Zealand's relatively benign experience of crisis means that pressures have not been so acute here. Blinder's survey, for example, suggested that pressure on central banks was particularly severe where they had undertaken quantitative easing and banks had to be rescued with public money (Blinder et al., 2017). However, with interest

\section{New Zealand's status as a small open economy means the impact of monetary policy on the exchange rate is likely to be a recurring issue.}

additional reasons to doubt the wisdom of inflation-targeting regimes in 'normal' times (Reichlin and Baldwin, 2013). However, as we saw in the previous section, inflation targeting always had its dissenters. Trust was vested in central bankers to do a genuine job of weighing up the trade-off between inflation and output in an even-handed way. If the central bank acquires other roles, where distributional outcomes are more open to question, there is a danger that distrust may spread, raising renewed concerns about central bankers' 'neutrality' even in their core trade of traditional monetary policy. In practice, Alan Blinder's extensive survey of central bankers and interested economists suggests that $94 \%$ of academics believed their central bank had been criticised for 'crossing the line' into political territory during the crisis, with over $70 \%$ seeing this as 'serious criticism' (Blinder et al., 2017).

\section{8 reforms to the New Zealand Reserve Bank Act}

The recent reforms, then, took place against a background of growing concern about the legitimacy of central bank rates still low and an uncertain global economic environment, New Zealand may yet need to pursue unconventional policy. Additionally, New Zealand's status as a small open economy means the impact of monetary policy on the exchange rate is likely to be a recurring issue. Finally, the single decision-maker model established in 1989 required particular faith in technocratic decision making and, at least formally, did little to encourage public engagement and explanation.

In the rest of this section, I review the 2018 reforms in the light of these challenges, beginning with changes to governance and moving on to the bank's policy mandate and tools.

Governance: committee decision making, institutional change and greater public engagement

Establishing a monetary policy committee was the least controversial reform. Debate concerned the constitution of the New Zealand Monetary Policy Committee and its communication strategy.

Committees have become the most common international arrangement, but 
their format and mode of operation varies. The 2018 legislation provides for the committee to have four internal (Reserve Bank) staff and three externals, plus a Treasury observer who can speak but not vote. The committee's charter ${ }^{7}$ looks most like what Blinder (2007) calls a 'collegial committee'. Members are required to debate respectfully and are expected to reach a consensus position where possible. The reasoning behind this consensus is to be communicated through a 'summary of discussions'. However, departing slightly from a full collegial model, that summary is explicitly required to include notice of any 'material differences of view or judgement' and voting is possible where consensus cannot be reached.
Nonetheless, the new structure does strengthen the role of external voices in the decision-making process (from acting as advisors to having a seat at the final table). It also publicly embodies a more deliberative and democratic vision of what central bank decision making is like. Economists have tended to be concerned with whether committee structures are more likely to get policy 'right'. From a political point of view, though, it is also important that central banks can be seen to be weighing up a range of considerations in making their decisions in a way that is, as far as possible, politically neutral. Here evidence that trade-offs are being discussed in a way that takes different preferences and points of view seriously ought to provide

\section{On politicisation, the minister now has a more direct role in shaping Monetary Policy Committee membership.}

The technical literature suggests that committees perform better on average, given that monetary policy is made under conditions of uncertainty. More people at the table should involve pooling information and rein in extreme opinions by subjecting them to debate based on a more diverse set of theoretical perspectives. However, to maximise these benefits it is important that committees function well, allowing respectful disagreement and avoiding too much deference to an autocratic chair. ${ }^{8}$

The difference between committeebased decision making and the Reserve Bank's previous practice shouldn't be exaggerated. The bank has long had a reputation for transparency and its procedures involved gathering wideranging information from a variety of sources, including external advisors, and procedural design that was intended to allow dissent and prevent groupthink (Richardson, 2016). Since Graeme Wheeler's tenure the governor has discussed decisions with three senior staff in an informal committee but remained formally accountable for final decisions. public reassurance and improve the quality of public debate. ${ }^{9}$ That is particularly important in times of heightened political contestation. Central bankers have sometimes been guilty of burnishing their inflation-fighting credentials for a market audience in ways that underplay the extent to which they are also concerned about not damaging output and employment. ${ }^{10}$ Seeing communications as directed at both markets and publics should help to redress this balance.

On the other hand, the main concerns expressed in debating the new rules were precisely that a committee structure would politicise monetary policy and undermine the Reserve Bank's ability to communicate with markets. ${ }^{11}$ Those concerns are understandable. The new model is a shift from a system that implied that a neutral governor could 'get policy right' to one that explicitly acknowledges contestable judgement about trade-offs with political consequences. However, trade-offs were always present and everyone knew that (Blinder, 2007). When governors made decisions in difficult circumstances, markets would know that those decisions risked reversal.Arguably, a well-functioning committee, communicating a more sophisticated understanding of how decisions were made, is also providing more accurate signals to markets (albeit signals that require interpretation, but that was also true before). It is fair to say, though, that the committee structure will make communication more challenging.

On politicisation, the minister now has a more direct role in shaping Monetary Policy Committee membership. However, the minister's external appointments must be on the board's recommendation and remain a minority of the committee. The production of minutes should at least make any politicisation transparent and the requirement for consensus deliberation should serve to push towards compromise policy solutions.

The legislation also makes some further minor changes that enhance transparency. Replacing the old policy targets agreement between minister and governor, the minister will produce a 'policy remit' for the committee, 'having regard to' bank advice. The remit is not likely to be radically different from an existing policy targets agreement. ${ }^{12}$ However, it does specifically allow the minister to provide guidance on how 'economic objectives' might be defined and on the relative priority between them (i.e. between output and price stability). What is new is a clearer requirement for public consultation about what the remit might contain, primarily through obligations on the Reserve Bank to consult the public before formulating its advice to the minister. More generally, there are enhanced provisions for public consultation relating to a range of decisions (including on the content of the Monetary Policy Committee charter), along with publication of outcomes and the reasons for them in ways that one might hope would feed into more effective public understanding and debate.

\section{The mandate, policy instruments and} emerging technical challenges for central banking

The shift to a dual mandate was more controversial (and opposed by National Party and ACT MPs). In parliamentary debate, Finance Minister Grant Robertson has generally argued that the new mandate 
does nothing to compromise financial stability and reflects the Reserve Bank's existing flexible inflation-targeting approach. ${ }^{13}$ However, as we saw above, all three coalition partners in the government have previously criticised the bank for putting too much weight on inflation rather than output. National, meanwhile, has argued that the change is either unnecessary and potentially risky (if it is not expected to change policy) or will water down price stability.

The mandate is carefully phrased and Treasury advice tends to suggest that it is intended to reflect current flexible inflation-targeting practice. The new legislation clarifies that the bank's mandate should be price stability 'over the medium term. ${ }^{14}$ It also adds a new mandate to 'support maximum sustainable employment'. Treasury tell us that: 'support' acknowledges that monetary policy has a limited impact on output; 'sustainable' affirms that the bank should minimise fluctuations around natural long-term employment levels (rather than create overheating through stimulus); and 'maximum' indicates maximisation in the context of other monetary policy choices (Treasury, 2018). Reserve Bank research on dual mandates elsewhere suggests that the shift is unlikely to have a significant impact on how monetary policy is carried out (Jacob and Wadsworth, 2018).

However, it is also not clear that the new mandate does much to deal with the economic situations in which New Zealand and overseas central banks have recently come under pressure. As we have seen, in New Zealand criticism has tended to revolve around the exchange rate. When criticism last emerged, in the aftermath of the global financial crisis, the bank responded by arguing that monetary policy could do nothing to resolve a situation in which high interest rates encouraged capital inflows and exchange rate overvaluation. That position implicitly relied on what, at the time, was the consensus view: that financial markets could be expected to act rationally in response to economic fundamentals.

Since the crisis, IMF researchers have led official recognition that, at times, exchange rate overvaluation can be the result of market failures in the form of self- fulfilling exchange rate expectations, encouraging a surge in capital inflows. Where fiscal and monetary policy are appropriate and the exchange rate is plainly overvalued, they suggest exchange market intervention may be appropriate and, failing that, 'prudential capital flow management' (Jeanne and Korinek, 2010; Korinek, 2011; Ostry, Ghosh and Chamon, 2012). IMF work still suggests that exchange rate operations are unlikely to be successful in a small, well-integrated economy like New Zealand's. That leaves either accepting the previous status quo and trusting that ever-improving public communication will maintain acceptance of the costs, or capital controls. The bank's 2013 change of heart in relation to 'emerging markets'. The large financial markets are unlikely to experience this kind of problem, so the global financial crisis has not produced the kind of official change in sentiment that might give the Reserve Bank 'safe cover' to implement controls (though 'emerging markets' include relatively large and sophisticated markets like Korea). For now, then, if the problem re-emerges, the bank will have to hope that its new tools of public communication can help convince the public that the pain involved is unavoidable: the sort of situation in which central banks are meant to have the independence to make tough choices.

The other big change in post-crisis

\section{In the wake of the global financial crisis, there has been growing pressure on central bank legitimacy due to new roles banks have taken on and to shifting public attitudes.}

communications were (presumably quite deliberately) silent on the possibility of capital controls. Capital controls are still seen by many as incompatible with a commitment to economic openness ${ }^{15}$ and there may have been concerns that even discussing controls could have negative impacts on inflows. However, the bank's new macroprudential tools, particularly loan-to-value limits on property lending and limits on banks' exposure to shortterm foreign borrowing (core funding ratio), could theoretically be used to reduce capital inflows as they flow through to the housing sector.

The present memorandum of understanding with the minister, which governs macroprudential tools, specifically limits their use to situations in which banking system stability is threatened. They can be used where inflows are sufficiently extreme to threaten financial crisis, but not simply as a tool of exchange rate management (unless that is changed as part of phase two reform, which seems unlikely). At present the IMF's discussions around 'flow controls' only suggest a economic thinking concerns policymaking in recessions once interest rates approach the zero lower bound. At that point, the possibility of greater fiscal-monetary policy coordination becomes important. In part that is because coordination is required to give credible signals that the authorities will do what it takes to restart inflation (Eggerston, 2013). Equally, once interest rates cease to work as a tool of monetary policy, it is no longer clear that the central bank has the best tools to deal with the business cycle. Traditionally, in inflation-targeting regimes, fiscalmonetary coordination has been avoided because a core reason for central bank independence is to ensure the bank is firmly in charge of stabilisation policy. However, in a deep recession, separation can deprive authorities of the best tools for the problem at hand. The Reserve Bank of New Zealand has done some research on policy options in this situation (Drought, Perry and Richardson, 2018). The presence of a Treasury representative on the Monetary Policy Committee opens up the possibility of informal coordination and a 
dual mandate may make it easier to produce credible signals (through, for example, an output target below which accommodatory conditions will persist). However, it would be better if the Reserve Bank and Treasury had got to the point of having a well-developed plan for both policy and institutional arrangements when this situation arises, ${ }^{16}$ particularly given that recent modelling suggests it could be a common problem in the future (Kiley and Roberts, 2017). The newly produced Monetary Policy Handbook currently bluntly states that quantitative easing is 'not necessary in New Zealand' (Williams, 2019, p.55).

\section{Conclusions}

In the wake of the global financial crisis, there has been growing pressure on central bank legitimacy due to new roles banks have taken on and to shifting public attitudes. In New Zealand pressures have not been acute, with only relatively lowlevel criticism of the bank in the post-crisis years. However, with interest rates low and the global economic outlook uncertain, it is important for the Reserve Bank to be prepared for stormy waters ahead.

The reforms so far institutionalise some existing good practice at the Reserve Bank and add some further incremental change. They are particularly welcome in codifying and extending a range of changes that should encourage greater public understanding of and engagement with the bank's activities. Explicitly adopting a dual mandate and moving to more transparent committee decision making both work towards greater visibility for the bank's role in carefully balancing growth and price staiblity.

However, it is unlikely that monetary policy will look very different as a result. When high interest rates produce exchange rate appreciation, the bank will need to work hard at its communication strategy in order to argue that the result is simply pain that needs to be borne in the interest of price stability. If New Zealand finds itself at the zero lower bound of interest rates while a recession continues, though (which seems at least reasonably likely), something quite different will need to be done and it would be a shame if the opportunity to think seriously about what that might look like were missed as part of this major review. Indeed, there is plenty more interesting and important work to be done in phase two, which includes a broader consideration of the bank's governance, its role in regulating the financial system and its policies for crisis management.

\footnotetext{
1 What follows is very condensed as the story has been told elsewhere. See, particularly, Singleton et al., 2006, chapter 5.

2 Partly because wealth effects dominate those on low incomes and partly because increased unemployment has a stronger impact than steady erosion of income through price level changes: see Monnin, 2017.

3 During Graeme Wheeler's term, inflation was consistently lower than target. More problematically, the Reserve Bank's inflation forecasts were consistently low, suggesting that the official cash rate was set too high. However, most other forecasters in New Zealand were also overestimating future inflation. See, particularly, Williams, 2017a, 2017b.
}

4 For contrasting views on how serious the problem was for New Zealand in the mid-2000s, see the papers produced for a Reserve Bank seminar on the topic in 2011: https:// treasury.govt.nz/publications/conference-paper/newzealands-macroeconomic-imbalances-\%E2\%80\%93-causesand-remedies-policy-forum-23-and-24-june-2011

5 See, for example, the 2008 special issue of Comparative European Politics, 6 (3), on 'The political cost of property booms'.

6 For the more technically inclined, there are also concerns that QE pushes central banks into fiscal territory because their expanded balance sheets interfere with Treasury's debt management and pose a potential risk to the taxpayer in the event of default and, potentially, to central banks' inflationfighting commitment.

7 Available at https://www.rbnz.govt.nz/-/media/ReserveBank Files/Monetary\%20policy/About\%20monetary\%20 policy/Monetary-Policy-Committee-Charter-April-2019. pdf? la =enandrevision =33f0b2ff-3845-432e-aad552f73dbe65ee.

8 The literature is large and can only get the briefest airing here. For a classic overview, see Blinder, 2007. For some recent empirical evidence, with some useful discussion of how insiders see committees working, see Apel et al., 2015. For contemporary Reserve Bank views, see Price and Wadsworth, 2019.

9 The literature on 'deliberative democracy' provides useful summaries of what ideal deliberation might look like and how 'elite' and 'popular' deliberation might fit together. See, for example, Gutman and Thompson, 2004; Mansbridge et al., 2010.

10 See particularly Mishkin, 2005, in which he argues concern with output has sometimes become a 'dirty little secret' among central bankers. For a critique of central banks' communication with publics, see Riles, 2018.

11 See Amy Adams' speech on the second reading of the bill (Hansard, 4 December 2018) and a variety of submissions to the Finance and Expenditure Select Committee.

12 The first remit is available at https://www.rbnz.govt.nz/-/ media/ReserveBank/Files/Monetary\%20policy/About\%20 monetary\%20policy/Remit-for-the-Monetary-PolicyCommittee-April-2019.pdf?la $=$ enandrevision $=a 5783 \mathrm{e} 23$ a90b-43d5-8769-75c448eef89b.

13 See Hansard for his opening speeches on the first (26 July 2018) and second (4 December 2018) readings of the bill.

14 In keeping with most recent policy target agreements.

15 For example, New Zealand is a party to the OECD's code for the liberalisation of capital movements. The OECD and IMF are engaged in long-term discussion about capital flows, though some controls would be possible if a registration was noted under Appendix B to the code.

16 Unfortunately, there is no current consensus position on what to do. International lessons so far are largely negative. They tell us most about what to avoid. However, that is all the more reason to have a plan. There are some interesting suggestions in the academic literature that are worthy of consideration. See, for example, Balls, Howat and Stansbury, 2016 and Bernanke, 2017

\section{References}

Adolph, C. (2013) Bankers, Bureaucrats, and Central Bank Politics: the myth of neutrality, Cambridge: Cambridge University Press

Alesina, A. and A. Stella (2010) 'The politics of moentary economics', in

B. Friedman and M. Woodford (eds), Handbook of Monetary Economics (Volume 3B), Amsterdam: North Holland

Apel, M., C.A. Claussen, P. Lennartsdotter and Ø. Røisland (2015)

"Monetary policy committees: comparing theory and "inside" information from MPC members', International Journal of Central Banking, 11 (4), pp.47-89

Balls, E., J. Howat and A. Stansbury (2016) Central Bank Independence Revisited: after the financial crisis, what should a model central bank look like?, M-RCBG associate working paper 67, Cambridge, Mass: Harvard Kennedy School

Bernanke, B. (2017) 'Monetary policy in a new era', paper prepared for the Rethinking Macroeconomic Policy conference, Peterson Institute, Washington DC, April, http://www.counter-striketv.com/ uploads/3/7/7/4/37740703/bernanke_rethinking_macro_final.pdf
Blinder, A. (2007) 'Monetary policy by committee: why and how?', European Journal of Political Economy, 23 (1), pp.106-23

Blinder, A., M. Ehrmann, J. De Haan and D.-J. Jansen (2017) 'Necessity as the mother of invention: monetary policy after the crisis', Economic Policy, 32 (92), pp.707-55

Buiter, W. (2014) Central Banks: powerful, political and unaccountable?, CEPR discussion paper 10223, London: CEPR

Bunn, P., A. Pugh and C. Yeates (2018) The Distributional Impact of Monetary Policy Easing in the UK between 2008 and 2014, Bank of England staff working paper 720, March

Drought, S., R. Perry and A. Richardson (2018) 'Aspects of unconventional monetary policy in New Zealand', Reserve Bank Bulletin, 81 (4), pp.1-22

Eggerston, G. (2013) 'Fiscal multipliers and policy coordination', in L.F. Cespedes and J.Galí (eds), Fiscal Policy and Macroeconomic Performance, Santiago: Central Bank of Chile

Eichbaum, C. (2009) 'The political economy of central banking in Australia and New Zealand', in K. Dyson and M. Marcussen (eds), Central 
Banks in the Age of the Euro: Europeanisation, convergence and power, Oxford: Oxford University Press

El-Erian, M. (2017) The Only Game in Town: central banks, instability and avoiding the next collapse, New York: Random House

Gutman, A. and D. Thompson (2004) Why Deliberative Democracy?, Princeton: Princeton University Press

Helleiner, E. (1994) States and the Reemergence of Global Finance: from Bretton Woods to the 1990s, New York; London: Cornell University Press

Jacob, P. and A. Wadsworth (2018) 'Estimated policy rules for different monetary regimes: flexible inflation targeting versus a dual mandate', Reserve Bank of New Zealand analytical notes, AN2018/11

James, H. (1996) International Monetary Cooperation since Bretton Woods, Washington; New York: International Monetary Fund and Oxford University Press

Jeanne, O. and A. Korinek (2010) 'Excessive volatility in capital flows: a Pigouvian taxation approach', American Economic Review, 100 (2), pp.403-5

Kiley, M. and J. Roberts (2017) 'Monetary policy in a low interest rate world', Brookings Papers on Economic Activity, 48 (1), Spring, pp.317-96

Kirshner, J. (2001) 'The political economy of low inflation', Journal of Economic Surveys, 15 (1)

Korinek, A. (2011) The New Economics of Capital Controls Imposed for Prudential Reasons, working paper WP/11/298, IMF

Mansbridge, J., J. Bohman, S. Chambers, D. Estlund, A. Føllesdal, A. Fung, C. Lafont, B. Manin and J.I. Martí (2010) 'The place of self-interest and the role of power in deliberative democracy', Journal of Political Philosophy, 18 (1), pp.64-100, doi:10.1111/j.1467-9760.2009.00344.x

Mishkin, F. (2005) 'The inflation targeting debate', John Kuszczak Memorial Lecture, Bank of Canada annual conference, May

Monnin, P. (2017) Monetary Policy, Macroprudential Regulation and Inequality, discussion note 2017/2, Council on Economic Policies

Ostry, J., A. Ghosh and M. Chamon (2012) Two Targets, Two Instruments: monetary and exchange rate policies in emerging markets, staff discussion note SDNB/12/01, Geneva: IMF
Posen, A. (1995) 'Declarations are not enough: financial sector sources of central bank independence', in B. Bernanke and J. Rotemberg (eds), NBER Macroeconomic Annual V.10, Cambridge, Mass: MIT Press

Price, G. and A. Wadsworth (2019) 'Effective monetary policy committee deliberation in New Zealand', Reserve Bank Bulletin, 82 (1)

Reichlin, L. and R. Baldwin (2013) 'Introduction', in L. Reichlin and R. Baldwin (eds), Is Inflation Targeting Dead? Central banking after the crisis, London: CEPR

Richardson, A. (2016) 'Behind the Scenes of an OCR Decision', Reserve Bank Bulletin, 79 (11), pp.1-15

Riles, A. (2018) Financial Citizenship: experts, publics and the politics of central banking, Ithaca: Cornell University Press

Singleton, J., A. Grimes, G. Hawke and F. Holmes (2006) Innovation and Independence: the Reserve Bank of New Zealand, Auckland: Auckland University Press

Svensson, L. (2001) Independent Review of the Operation of Monetary Policy in New Zealand: report to Minister of Finance

Treasury (2018) Reserve Bank of New Zealand (Monetary Policy) Amendment Bill: initial briefing to the Finance and Expenditure Committee, 3 September

Walsh, C. (1995) 'Is New Zealand's Reserve Bank Act of 1989 an optimal central bank contract?', Journal of Money, Credit and Banking, 27 (4.1), pp.1179-91

Wheeler, G. (2013) 'Manufacturing decline not just a dollar story', speech to the New Zealand Manufacturers and Exporters Association, Auckland, 20 February, https://www.rbnz.govt.nz/research-andpublications/speeches/2013/speech2013-02-20

Williams, R. (2017a) 'Business cycle review: 2008 to the present day', Reserve Bank Bulletin, 80 (2), pp.1-22

Williams, R. (2017b) 'Characterising the current economic expansion: 2009 to the present day', Reserve Bank Bulletin, 80 (3), pp.1-22

Williams, R. (ed.) (2019) Monetary Policy Handbook, Wellington: Reserve Bank of New Zealand

Wren-Lewis, S. (2011) 'Lessons from failure: fiscal policy, indulgence and ideology', National Institute Economic Review, 217 (1), pp.R31-46

\section{Victoria Professional and Executive Development}

High quality professional and executive development courses specifically designed for the public sector:

\section{MENTAL HEALTH AWARENESS WORKSHOP}

$\rightarrow$ Thu 5 September 2019, 9am-4:30pm

\section{MACHINERY OF GOVERNMENT}

$\rightarrow$ Wed 17 July 2019, 9am-4:30pm

$\rightarrow$ Thu 12 September 2019, 9am-4:30pm

\section{PUBLIC POLICY FUNDAMENTALS}

$\rightarrow$ Tue 18 June 2019, 9am-4:30pm

$\rightarrow$ Thu 15 August 2019, 9am-4:30pm

\section{PROCUREMENT AND CONTRACTING IN THE PUBLIC SECTOR}

$\rightarrow$ Wed 5 June 2019, 9am-4:30pm

$\rightarrow$ Wed 18 September 2019, 9am-4:30pm

\section{ENGAGING EFFECTIVELY WITH YOUR STAKEHOLDERS}

$\rightarrow$ Tue 13 August 2019, 9am-4:30pm

\section{CROWN-MĀORI RELATIONS: TREATY AND MORE \\ $\rightarrow$ Tue 4 \& Thu 6 June 2019, 9am-1pm \\ $\rightarrow$ Tue 15 \& Fri 18 October 2019, 9am-1pm}

We can also deliver in-house courses, customise existing courses or design new programmes to suit your requirements. We now also run courses at our Auckland training rooms. For more course dates, further information and to enrol visit www.victoria.ac.nz/profdev or call us on 04-463 6556. 